\title{
Identification and molecular characterization of mutations in Nucleocapsid Phosphoprotein of SARS-CoV-2
}

\author{
Gajendra Kumar Azad ${ }^{\text {Corresp. } 1}$ \\ ${ }^{1}$ Department of Zoology, Patna University, Patna, Bihar, India \\ Corresponding Author: Gajendra Kumar Azad \\ Email address: gkazad@patnauniversity.ac.in
}

SARS-CoV-2 genome encodes four structural protein that include, Spike glycoprotein, Membrane protein, Envelope protein and Nucleocapsid Phosphoprotein (N-protein). The Nprotein interacts with viral genomic RNA and helps in packaging. As the SARS-CoV-2 spread to almost all countries worldwide within 2-3 months; it also acquired mutations in its RNA genome. Therefore, this study was conducted with an aim to identify the variations present in N-protein of SARS-CoV-2. Here, we analysed 4163 reported sequence of Nprotein from United States of America (USA) and compared with first reported sequence from Wuhan, China. Our study identified 107 mutations that reside all over the N-protein. Further, we show the high rate of mutations in intrinsically disordered regions (IDRs) of $\mathrm{N}$ protein. Our study show $45 \%$ residues of IDR2 harbour mutations. The RNA-binding domain (RBD) and dimerization domain of $\mathrm{N}$-protein also have mutations at key residues. We further measured the effect of these mutations on N-protein stability and dynamicity and our data reveals that multiple mutations can cause considerable alterations. Altogether, our data strongly suggests that $\mathrm{N}$-protein is one of the mutational hotspot proteins of SARS-CoV-2 that is changing rapidly and these mutations can potentially interferes with various aspects of $\mathrm{N}$-protein functions including its interaction with RNA, oligomerization and signalling events. 
1 TITLE

2 Identification and molecular characterization of mutations in Nucleocapsid Phosphoprotein of

3 SARS-CoV-2

4

5 AUTHORS

6 Gajendra Kumar Azad ${ }^{1 \#}$

7

8 1Department of Zoology, Patna University, Patna-800005, Bihar (India)

9 \#Corresponding Author:

10 Gajendra Kumar Azad

11 Email address: gkazad@patnauniversity.ac.in

12

13

Keywords: COVID-19; SARS-CoV-2; Mutations; Nucleocapsid Phosphoprotein (N-protein);

14 Infectious diseases; USA

15

16

17

18

19

20

21

22

23

24

25

26

27

28 


\section{ABSTRACT}

SARS-CoV-2 genome encodes four structural protein that include, Spike glycoprotein, Membrane protein, Envelope protein and Nucleocapsid Phosphoprotein (N-protein). The Nprotein interacts with viral genomic RNA and helps in packaging. As the SARS-CoV-2 spread to almost all countries worldwide within 2-3 months; it also acquired mutations in its RNA genome. Therefore, this study was conducted with an aim to identify the variations present in N-protein of SARS-CoV-2. Here, we analysed 4163 reported sequence of N-protein from United States of America (USA) and compared with first reported sequence from Wuhan, China. Our study identified 107 mutations that reside all over the N-protein. Further, we show the high rate of mutations in intrinsically disordered regions (IDRs) of N-protein. Our study show $45 \%$ residues of IDR2 harbour mutations. The RNA-binding domain (RBD) and dimerization domain of Nprotein also have mutations at key residues. We further measured the effect of these mutations on $\mathrm{N}$-protein stability and dynamicity and our data reveals that multiple mutations can cause considerable alterations. Altogether, our data strongly suggests that $\mathrm{N}$-protein is one of the mutational hotspot proteins of SARS-CoV-2 that is changing rapidly and these mutations can potentially interferes with various aspects of $\mathrm{N}$-protein functions including its interaction with RNA, oligomerization and signalling events.

\section{INTRODUCTION}

In the late December, 2019, Wuhan, the Hubei province of China, reported a surge in hospitalisation due to pneumonia like symptoms (Zhu et al., 2020). The causative agent was identified as a severe acute respiratory syndrome coronavirus 2 (SARS-CoV-2) that shares close similarity with earlier known SARS-CoV (Chen et al., 2020). The SARS-CoV-2 is highly contagious that lead to its rapid spread worldwide, and in March 2020, the World Health Organization (WHO) declared the outbreak a pandemic. The disease caused by SARS-CoV-2 has been named as coronavirus disease 19 (COVID-19) that exhibits mild to severe respiratory distress in the infected individuals. As of $28^{\text {th }}$ June, 2020 the COVID-19 has affected all countries worldwide with close to 10 million reported cases and 0.5 million confirmed deaths. Further, the epidemiological studies revealed that the mortality rate from COVID-19 is significantly higher among individuals over 60 years of age with weak immunity (Liu et al., 2020). 
The SARS-CoV-2 has positive sense, single stranded RNA genome of approximately $29.8 \mathrm{~kb}$ (Wu et al., 2020b). The majority of viral genome encodes non-structural proteins that are proteolytically processed from a single Orf1ab polypeptide. SARS-CoV-2 genome also encode four structural proteins, including the Spike glycoprotein (S), Membrane protein (M), Envelope protein (E) and Nucleocapsid Phosphoprotein (N) (Wu et al., 2020a). The S, M and E proteins are located in the lipid bilayer of the virus and contribute to the formation of viral envelope; however, the N-protein contributes to the viral genomic RNA packaging and remains embedded in the central core of the virion. N-protein binds with viral genomic RNA and forms helical structure to maintain the structural integrity of RNA genome (Chang et al., 2014). This is one of the most abundant structural proteins encoded by the SARS-CoV-2 genome. The SARS-CoV-2 $\mathrm{N}$-protein resembles $\mathrm{N}$-protein from other RNA viruses, known to modulate host intracellular machinery and also involved in the regulation of virus life cycle (McBride, van Zyl \& Fielding, 2014). Evidence show that $\mathrm{N}$-protein is recruited to the Replication-Transcription Complexes (RTC) via Nsp3 and plays a crucial role in coronaviral life cycle (Cong et al., 2019). The abrogation of this interaction impairs the stimulation of genomic RNA and viral mRNA transcription in vivo and in vitro. Furthermore, the $\mathrm{N}$-protein interactions with $\mathrm{M}$ promotes completion of viral assembly by stabilizing $\mathrm{N}$ protein-RNA complex, inside the internal virion (Astuti \& Ysrafil, 2020).

The crystal structure of $\mathrm{N}$-protein revealed two distinct domains at $\mathrm{N}$ and $\mathrm{C}$ terminus (Kang et al., 2020). The domain present towards the $\mathrm{N}$ terminus is also known and RNA-binding domain (RBD). The $\mathrm{C}$ terminal side harbours dimerization domain which interacts with other $\mathrm{N}$-protein to make dimer. Apart from these two domains there are three intrinsically disordered regions (IDRs) at $\mathrm{N}$ and $\mathrm{C}$ terminal ends as well as between the RBD and dimerization domain of $\mathrm{N}$ protein. Since, this protein plays critical role in packaging of SARS-CoV-2 RNA genome, the mutations in N-protein or interfering its function can lead to diverse outcome on viral life cycle (Rabi Ann Musah, 2005; Chenavas et al., 2013).

Moreover, the study of $\mathrm{N}$-protein is also important because of its unique immunological properties. For instance, earlier study with SARS N-protein has shown that this protein is a potential candidate for vaccine development because it can induce a strong immunological response (Liu et al., 2006). A recent study revealed that the $B$ and $T$ cell epitopes of $N$ protein of SARS-CoV-2 shows close resemblance with that of SARS-CoV indicating that immune targeting of these identical epitopes may offer protection against this virus (Ahmed, Quadeer \& McKay, 2020). Moreover, the sera of COVID-19 patients contains abundant amount of $\lg A$, IgM and $\lg G$ antibodies against $\mathrm{N}$-protein antigen demonstrating the importance of this antigen in host 
103 immunity and diagnostics (Shang et al., 2005; Zeng et al., 2020). Therefore, the N-protein is one

104 of the candidate target molecule that needs to be properly studied to understand its role in virus

105 pathogenesis, vaccine development and pharmacological implications. Here, we compared the

$106 \mathrm{~N}$-protein sequences obtained from USA with first reported sequence from China to identify the

107 variations present between them. We have identified 107 mutations and their impact on $\mathrm{N}$ -

108 protein structure and function are discussed.

109

110

\section{MATERIALS AND METHODS}

Sequence retrieval from NCBI-virus-database

The NCBI-virus-database stores the deposited sequences of SARS-CoV-2 which is updated regularly as the new sequences are reported. As of $23^{\text {rd }}$ June 2020, 4163 SARS-CoV-2 sequences of $\mathrm{N}$-protein were deposited from USA. We downloaded these sequences and used them for analysis in this study. The first reported N-protein sequence from Wuhan was used as reference sequence or wild type sequence (Wu et al., 2020b). The protein accession identification number of reference sequence used in this study is YP_009724397 and rest of the 4163 IDs (reported from USA) are mentioned in supplementary table 1.

119

Multiple sequence alignment by Clustal-Omega program multiple sequence alignments and compared them with the first reported $\mathrm{N}$-protein sequence (YP_009724397) from Wuhan, China as described earlier (Azad, 2020). The multiple sequence alignment was performed using Clustal Omega tool (Madeira et al., 2019).

Calculation of free energy and vibrational entropy between wild type and mutant $N$-proteins In order to measure the impact of mutations identified in this study on the structural dynamicity and stability of $\mathrm{N}$-protein, we calculated the differences in free energy $(\Delta \Delta \mathrm{G})$ and vibrational entropy ( $\Delta \Delta$ Svib) ENCoM between wild type and mutants as described earlier (Chand, Banerjee \& Azad, 2020a). This analysis was performed by DynaMut program (Rodrigues, Pires \& Ascher, 2018). To perform DynaMut protein modelling we used RCSB protein ID: 6VYO (Kang et al., 2020) for RBD molecular modelling and RCSB protein ID: 6WJI for dimerization domain molecular modelling of N-protein. DynaMut also provide the visual representation of fluctuation in protein structure. The blue colour represents gain in rigidity and red colour represents gain in flexibility upon mutation. 
137

138

139

140

141

142

143

144

145

146

147

148

149

150

151

152

153

154

155

156

157

158

159

160

161

162

163

164

165

166

167

168

169

\section{Structural representation of $\mathrm{N}$-protein domains}

The UCSF Chimera program (Pettersen et al., 2004) was used for the interactive visualization and analysis of molecular structures and related data. High-quality images were generated as output file from this program. For structural representation, RCSB protein ID: 6VYO and 6WJI was used for RNA-binding domain and dimerization domain of $\mathrm{N}$-protein respectively.

\section{Generation of weblogo to show conservation of N-protein sequences}

The weblogo was generated using a webserver as described earlier (Crooks et al., 2004). The overall height of the stack indicates the sequence conservation at that position. For this analysis, all N-protein sequences (4163) reported from USA and the reference sequence (YP_009724397) was used. The sequence logo was generated by multiple sequence alignment of these $\mathrm{N}$-protein sequences.

\section{RESULTS}

Identification of mutations in IDR1, IDR2 and IDR3 of N-protein

The crystal structure of N-protein of SARS-CoV-2 has been recently solved (Kang et al., 2020), the structural details show it is comprised of three distinct regions; the $\mathrm{N}$ terminal domain (contains RNA-binding domain), $\mathrm{C}$ terminal domain (contains dimerization domain) and IDRs as shown in figure 1. There are three IDRs in N-protein; IDR1 (at the $\mathrm{N}$ terminal end), IDR2 (between RBD and CTD) and IDR3 (at the $C$ terminal end). IDR2 is also referred as linker region (LKR) because it connects $\mathrm{RBD}$ and dimerization domain of N-protein. In order to identify the variations present in N-protein of SARS-CoV-2 reported from the USA, we performed multiple sequence alignments. Here, we used Clustal Omega program to align $4163 \mathrm{~N}$-protein polypeptide sequences from USA and compared them with the first reported sequence from Wuhan, China.

Our analysis identified eighteen mutations in IDR1 (Table1). The IDR1 is present from 1-43 residues towards the $\mathrm{N}$ terminal end of $\mathrm{N}$-protein. These eighteen mutations correspond to approximately $40 \%$ (18 out of 43 ) of the residues of IDR1. Among these the most frequently mutated residues are Gly and Arg (both are mutated at four positions) and Pro residue is mutated at three different positions in IDR1 (Table 1).

Similar analysis with IDR2 identified thirty six mutations which correspond to approximately $45 \%$ of residues of IDR2 (Table 2). The IDR2 is present from 181-256 residues of the N-protein and connects RBD and dimerization domains. The most frequently mutated residue in IDR2 was 
170 found to be Ser, it is mutated at twelve positions. Further, the Ala, Gly and Arg residues are

171 mutated at five positions, respectively.

172 Similarly, we identified fifteen mutations in IDR3 (Table 3). The IDR3 is present from 365-419

173 residues towards the $\mathrm{C}$ terminal end of $\mathrm{N}$-protein. Most notable mutations are Thr and Ala

174 residues are mutated at three positions and Pro, Asp, and GIn are mutated at two positions,

175 respectively (Table 3 ). Altogether, we identified sixty nine mutations in intrinsically disordered

176 regions IDR1, IDR2 and IDR3 of N-protein.

177

178

Identification of mutations in RBD and dimerization domain of N-protein

179 The RBD of $\mathrm{N}$-protein starts from $44^{\text {th }}$ residue till $180^{\text {th }}$ residue. We mapped the mutation in this

180 region of $\mathrm{N}$-protein and our analysis revealed presence of twenty two mutations (Table 4).

181 These twenty two mutations also correspond to approximately $16 \%$ of the residues of RBD. Our

182 mutational analysis shows the most frequently mutated residues are Pro and Ala at five

183 positions and Asp at three positions as shown in table 4.

184 Similar analysis with the dimerization domain of N-protein revealed that it harbours sixteen

185 mutations (Table 5). The dimerization domain of $\mathrm{N}$-protein starts from $257^{\text {th }}$ residue till $364^{\text {th }}$

186 residue. Our mutational analysis shows Thr is mutated at four positions and Asp at three

187 positions. Further, only $14 \%$ residues are mutated in this domain which is least among all other

188 regions of the $\mathrm{N}$-protein identified here. Altogether, we identified thirty eight mutations in RBD

189 and dimerization domain of $\mathrm{N}$-protein. We have highlighted the location of amino acids in the

190 representative crystal structure of N-protein that are mutated in RBD (Figure 1B) and

191 dimerization domain (Figure 1C)

192 Subsequently, we also calculated the frequency of each mutation identified in this study. The

193 table 6 shows the top ten mutants arranged in descending order of their respective frequencies.

194 The R203K mutation is having the highest frequency of 4.9\% followed by G204R with $4.7 \%$.

195 Further, we generated weblogo of the 4163 polypeptide sequences of N-protein to observe their

196 amino acid conservation as shown in figure 2. Altogether, we have identified 107 mutations in

$197 \mathrm{~N}$-protein that resides in its IDRs and RBD and dimerization domain.

\section{Mutations causes alteration in dynamic stability of $\mathrm{N}$-protein}

200 In order to understand the effect of mutations on the stability of the protein we calculated the

201 differences in free energy $(\Delta \Delta \mathrm{G})$ between wild type and mutants. We performed this analysis

202 using DynaMut program. The positive $\Delta \Delta G$ corresponds to increase in stability while negative

$203 \Delta \Delta G$ corresponds to decrease in stability. We performed this analysis with all of the mutations 
204 that reside in RBD and dimerization domain of N-protein. The IDRs do not have proper 3D

205

206

207

208

209

210

211

212

213

214

215

216

217

218

219

220

221

222

223

224

225

226

227

228

229

230

231

232

233

234

235

236

237

structure therefore; this analysis is not accurate for those regions. Our data revealed the noticeable increase or decrease in free energy in various mutations as shown in table 6 . The top five positive and negative $\Delta \Delta G$ values are highlighted in table 6 . The maximum increase in $\Delta \Delta G$ was observed for T271I (1.184 kcal $/ \mathrm{mol})$ and the highest negative $\Delta \Delta \mathrm{G}$ was obtained for I292T $(-1.952 \mathrm{kcal} / \mathrm{mol})$, both of these mutations reside in dimerization domain of $\mathrm{N}$-protein.

We also measured the change in vibrational entropy energy ( $\left.\Delta \Delta \mathrm{S}_{\text {Vib }} E N C o M\right)$ between the wild type and the mutants present in RBD and dimerization domain of N-protein (Table 7).Vibration entropy contributes to the configurational-entropy of the proteins (Goethe, Fita \& Rubi, 2015).

The negative $\Delta \Delta \mathrm{S}_{\mathrm{Vib}} \mathrm{ENCoM}$ of mutant $\mathrm{N}$-protein corresponds to the increase in rigidification and positive $\Delta \Delta S_{\mathrm{Vib}} E N C o M$ corresponds to gain in flexibility of the protein structure. The maximum positive $\Delta \Delta \mathrm{S}_{\mathrm{Vib}} \mathrm{ENCoM}$ was obtained for P364L (0.256 kcal.mol-1.K-1) and negative $\Delta \Delta \mathrm{S}_{\mathrm{Vib}} \mathrm{ENCoM}$ was obtained for G284E (-0.844 kcal.mol-1.K-1). The variation in vibrational entropy between wild type and mutant can also be visualised as shown in figure 3 . The blue colour corresponds to rigidification in protein structure and red colour corresponds to gain in flexibility upon mutation. The top three positive and negative $\Delta \Delta S_{\text {Vib }} E N C o M$ are shown in figure $3(A-F)$. Altogether, the data obtained from $\Delta \Delta G$ and $\Delta \Delta S_{V i b} E N C o M$ strongly suggests that the mutations identified in this study can influence $\mathrm{N}$-protein stability and dynamicity.

\section{Intramolecular interactions are altered due to mutations in N-protein}

Next, we sought to closely analyse the changes in the intramolecular interactions in some of the mutants that exhibited significant alterations in $\Delta \Delta \mathrm{G}$. We compared the intramolecular interaction for T271I ( $\Delta \Delta \mathrm{G}: 1.184 \mathrm{kcal} / \mathrm{mol})$ and I292T $(\Delta \Delta \mathrm{G}:-1.952 \mathrm{kcal} / \mathrm{mol})$ as these two mutants showed maximum variations among thirty eight mutants present in RBD and dimerization domain of $\mathrm{N}$-protein (Table 4 and 5). Our data clearly showed the variations in the interactions mediated by wild type and mutant residues in the pocket, where these amino acids resides as shown in figure 4A-B (T271I), and 4C-D (I292T). Altogether, our data strongly suggests that the mutants identified in our study are affecting the dynamic stability as well as intramolecular interactions in the N-protein.

\section{DISCUSSIONS}

SARS-CoV-2 is an RNA virus, a causative agent of COVID-19. This virus spread worldwide within a span of few months and during its spread it also acquired mutations. Several recent studies reported the appearance of mutations in SARS-CoV-2 proteins (Korber et al., 2020; 
238 Pachetti et al., 2020; Chand, Banerjee \& Azad, 2020b). This study was performed with an aim to 239 identify mutations in N-protein which is one of the main structural proteins of SARS-CoV-2.

240 Here, we analysed 4163 sequences of N-protein from USA and identified 107 mutations upon

241 comparison from first reported sequences of the same protein from Wuhan, China. We also

242 observed around 64\% (69 out of 107) of these mutations reside in the IDRs of N-protein. Among

243 IDRs, the IDR2 harbours 36 mutations that correspond to the most number of mutations

244 observed in a single distinct region of the N-protein.

245 Earlier studies demonstrated that Ser and Arg-rich linker region (IDR2) plays indispensible role

246 in intracellular signalling events primarily by phosphorylation at Ser residues (Wootton, Rowland

247 \& Yoo, 2002; McBride, van Zyl \& Fielding, 2014). The wild type LKR/ IDR2 contains sixteen Ser

248 residues, and our study revealed that out of those, twelve serine residues are mutated (table 2).

249 Therefore, we can safely assume that these mutations of Ser residues might contribute to

250 alteration of phosphorylation dependent signalling. A recent study shows that S197, S202,

251 R203 and G204 are important sites of phosphorylation by Aurora kinase A/B, GSK-3 as well as

252 for its interactions with 14-3-3 protein (Tung \& Limtung, 2020). Surprisingly, our study report

253 mutation in all of these four residues suggesting that these mutant might have altered

254 phosphorylation signaling. We have also observed that R203 and G204 is the most frequently

255 mutated residue of N-protein (Table 6). Similar observations were also reported from other

256 locations (Franco-Munoz et al., 2020). Furthermore, two recent independent studies revealed

257 that SARS-CoV-2 is capable of suppressing the type-I IFN innate immune pathway possibly due

258 to the role of N-protein in signalling events (Blanco-Melo et al., 2020; Zhou et al., 2020a) which

259 can potentially alter the virulence of SARS-CoV-2.

260 We also measured $\Delta \Delta G$ and $\Delta \Delta S_{V i b} E N C o M$ for the mutants that reside in the RBD and

261 dimerization domain of $\mathrm{N}$-protein. The four mutants that exhibited highest values for $\Delta \Delta \mathrm{G}$ and

$262 \Delta \Delta S_{V i b} E N C o M$ identified in our study are T271I, I292T, G284E and P364L. Since, all of them

263 are in the dimerization domain; therefore, it is possible that these mutations might lead to

264 alteration in the dimerization potential of N-protein. The structural study of N-protein (C terminal

265 domain) has revealed that residue 247-279 are essential for RNA binding (Zhou et al., 2020b)

266 which harbours seven mutations (T247A, K249R, S250F, A252S, S255A, V270L

267 T271I). The occurrence of these mutations in $C$ terminal domain could possibly affect its

268 interaction with RNA that might translate into viral RNA packaging and stability. Furthermore,

269 the N-protein is also proposed as a candidate for vaccine development because it is known to

270 elicit strong immunological response in SARS-CoV infected patients (Lin et al., 2003). A recent

271 study shows that several B cell epitope of SARS-CoV were identical with SARS-CoV-2 (Ahmed, 
272 Quadeer \& McKay, 2020). This study revealed that one of the most important B and T cell

273 epitope lies between residues 305-340 of N-protein; however, our study identified multiple

274 mutations including, P309L, M322I, S327L, T329M, T334I, D340G, D340N in that stretch.

275 Therefore, it is possible that due to these mutations the properties of epitope might change that

276 can affect host immunological response. Another mutation, P344S mutation has been

277 implicated to decrease the protein stability (Khan et al., 2020). Hence, the development of

278 vaccines that target SARS-COV-2 N-protein must consider the mutations that occur in various

279 populations and locations.

280 Evidences indicate that the N-protein of coronaviruses functions as an RNA chaperones (Zúñiga

281 et al., 2007, 2010) and also contributes to packaging and maintenance of the RNA genome. It is

282 also involved in RNA metabolism because $\mathrm{N}$-protein interaction assays have shown the core

283 stress granule components G3BP1 and G3BP2 are its interacting partners (Gordon et al.,

284 2020). This interaction can either enhance stress granule induction or inhibit stress granule

285 formation by sequestering G3BP1/G3BP2 (Hou et al., 2017). Hence, the drugs that can either

286 inhibit the interactions of RNA with N-protein or interfere with dimerization of N-protein can be a

287 potential antiviral candidates (Lo et al., 2013). One such drug is Nucleozin and its derivatives

288 that targets ribonucleoprotein formation in influenza virus by interfering N-protein

289 oligomerization (Gerritz et al., 2011). Furthermore, a recent study was conducted to identify

290 inhibitors of SARS-CoV-2 N-protein, identified various promising candidate drugs including

291 Conivaptan, Ergotamine, Venetoclax and Rifapentine (Onat Kadioglu, 2020). These candidate

292 drugs interact with the residues that are either mutated (residue 154, 155, 156, 166) or are in

293 the close vicinity of the mutations (residue $67,81,163,169$ ) identified in our study. Furthermore,

294 bioinformatics analysis predicted Dihydroergotamine, Rifabutin and Nystatin as a potential

295 candidate drugs (Onat Kadioglu, 2020) that interacts with a stretch of residues (from residues

296150 to 160 ) of N-protein. Surprisingly, our study revealed that this stretch harbour four mutations

297 (151, 152, 154 and 156), which can potentially alter the interactions of these drugs with N-

298 protein. Altogether, the mutation revealed in this study can interfere with various aspects of $\mathrm{N}$ -

299 protein functions that include oligomerization, interaction with RNA and interference in N-protein

300 mediated signalling events.

301

302

\section{CONCLUSIONS}

303 In this study we identified 107 mutations in N-protein of SARS-CoV-2 reported from USA.

304 Further, we demonstrate these mutations can potentially alter dynamic stability of N-protein. 
305

306

307

308

309

310

311

312

313

314

315

316

317

318

319

320

321

322

323

324

325

326

327

328

329

330

331

332

333

334

335

336

337

338

Altogether, the data presented here, warrants further investigations to understand its impact on SARS-CoV-2 phenotype and drugs that target N-protein.

\section{ACKNOWLDEGEMENTS}

We would like to acknowledge the Department of Zoology, Patna University, Patna, Bihar (India) for providing infrastructural support for this study.

\section{FIGURE AND TABLE LEGENDS}

Figure 1: The schematic structure of Nucleocapsid Phosphoprotein (N-protein) of SARS-CoV-2. The N-protein is comprised of 419 residues. The RNA-binding domain, dimerization domain, intrinsically disordered regions including IRD1, IRD2, and IRD3 are labelled. B-C) Cartoon representation of crystal structure of the RNA-binding domain (RCSB protein ID-6VYO) and dimerization domain (RCSB protein ID-6WJI) of N-protein. Panel B demonstrates the RBD while panel $\mathrm{C}$ represents dimerization domain of $\mathrm{N}$-protein. The identified mutated amino acids (single letter code) along with its respective position in polypeptide sequence are shown. The structural representations were made using UCSF chimera software tool.

Figure 2: The weblogo diagram showing the conservation status of polypeptide sequence of $\mathrm{N}$ protein. The sequence weblogo was generated by multiple sequence alignment of $4164 \mathrm{~N}$ protein sequences. The overall height of the stack indicates the sequence conservation at that position.

Figure 3: Visual representation of $\Delta$ Vibrational Entropy Energy between Wild-Type and Mutant $\mathrm{N}$-protein. The amino acids residues are colored according to the vibrational entropy change as a consequence of mutation of $\mathrm{N}$-protein. BLUE, represents a rigidification of the structure and RED, a gain in flexibility. (A-C) represents the top three mutants that show rigidification in structure upon mutation. (D-F) represents the top three mutants that show gain in flexibility upon mutation. Each panel also shows the mutation and the location of the residues.

Figure 4: Visual representation of interatomic interactions contributed by T271I and I292T of Nprotein. Both of these mutants showed maximum positive and negative $\Delta \Delta G$ among mutants present in RBD and dimerization domain of N-protein. (A-B) represents threonine to isoleucine substitution at $271^{\text {st }}$ position; (C-D) represents isoleucine to threonine substitution at $292^{\text {nd }}$ position. Wild-type and mutant residues are represented in light-green color. The interactions 
339

340

341

342

343 344

345

346

347 348

349 350

351

352

353

354

355

356

357

358

359

360

361

362

363

364

365

366

367

368

369

370

371

372

made by wild type and mutant residues are highlighted in each panel. The polar interactions are depicted in red dotted line, hydrophobic interaction in green and weak hydrogen bonds in orange.

Table 1: The table show the location and details of mutations identified in IDR1 of N-protein.

Table 2: The table show the location and details of mutations identified in IDR2.

Table 3: The table show the location and details of mutations identified in IDR3.

Table 4: The table show the location and details of mutations identified in RBD of N-protein.

Table 5: The table show the location and details of mutations identified in dimerization domain of $\mathrm{N}$-protein.

Table 6: The frequency of top ten mutations observed in our study

Table 7: The table show the $\Delta \Delta \mathrm{G}$ and $\Delta \Delta$ Svib ENCoM of the mutants present in RBD and dimerization domain of N-protein. DynaMut program was used to calculate both parameters. The top five positive and negative $\Delta \Delta G$ values are highlighted in bold digits. The top three positive and negative $\Delta \Delta$ Svib ENCoM values are highlighted in bold digits.

\section{REFERENCES}

Ahmed SF, Quadeer AA, McKay MR. 2020. Preliminary identification of potential vaccine targets for the COVID-19 Coronavirus (SARS-CoV-2) Based on SARS-CoV Immunological Studies. Viruses. DOI: 10.3390/v12030254.

Astuti I, Ysrafil. 2020. Severe Acute Respiratory Syndrome Coronavirus 2 (SARS-CoV-2): An overview of viral structure and host response. Diabetes and Metabolic Syndrome: Clinical Research and Reviews. DOI: 10.1016/j.dsx.2020.04.020.

Azad GK. 2020. Identification of novel mutations in the methyltransferase complex (Nsp10Nsp16) of SARS-CoV-2. Biochemistry and Biophysics Reports. DOI: 10.1016/j.bbrep.2020.100833.

Blanco-Melo D, Nilsson-Payant BE, Liu WC, Uhl S, Hoagland D, Møller R, Jordan TX, Oishi K, Panis M, Sachs D, Wang TT, Schwartz RE, Lim JK, Albrecht RA, tenOever BR. 2020. 
373

374

375

376

377

378

379

380

381

382

383

384

385

386

387

388

389

390

391

392

393

394

395

396

397

398

399

400

401

402

403

404

405

406

Imbalanced Host Response to SARS-CoV-2 Drives Development of COVID-19. Cell. DOI: 10.1016/j.cell.2020.04.026.

Chand GB, Banerjee A, Azad GK. 2020a. Identification of twenty-five mutations in surface glycoprotein (Spike) of SARS-CoV-2 among Indian isolates and their impact on protein dynamics. Gene Reports 21. DOI: 10.1016/j.genrep.2020.100891.

Chand GB, Banerjee A, Azad GK. 2020b. Identification of novel mutations in RNA-dependent RNA polymerases of SARS-CoV-2 and their implications on its protein structure. PeerJ 8:e9492. DOI: 10.7717/peerj.9492.

Chang CK, Hou MH, Chang CF, Hsiao CD, Huang TH. 2014. The SARS coronavirus nucleocapsid protein - Forms and functions. Antiviral Research. DOI: 10.1016/j.antiviral.2013.12.009.

Chen N, Zhou M, Dong X, Qu J, Gong F, Han Y, Qiu Y, Wang J, Liu Y, Wei Y, Xia J, Yu T, Zhang X, Zhang L. 2020. Epidemiological and clinical characteristics of 99 cases of 2019 novel coronavirus pneumonia in Wuhan, China: a descriptive study. The Lancet. DOI: 10.1016/S0140-6736(20)30211-7.

Chenavas S, Cre pin T, Delmas B, Ruigrok RWH, Slama-Schwok A. 2013. Influenza virus nucleoprotein: Structure, RNA binding, oligomerization and antiviral drug target. Future Microbiology. DOI: 10.2217/fmb.13.128.

Cong Y, Ulasli M, Schepers H, Mauthe M, V'kovski P, Kriegenburg F, Thiel V, de Haan CAM, Reggiori F. 2019. Nucleocapsid Protein Recruitment to Replication-Transcription Complexes Plays a Crucial Role in Coronaviral Life Cycle. Journal of Virology. DOI: 10.1128/jvi.01925-19.

Crooks GE, Hon G, Chandonia JM, Brenner SE. 2004. WebLogo: A sequence logo generator. Genome Research. DOI: 10.1101/gr.849004.

Franco-Munoz C, Alvarez-Diaz DA, Laiton-Donato K, Wiesner M, Escandon P, Usme-Ciro JA, Franco-Sierra ND, Florez-Sanchez AC, Gomez-Rangel S, Calderon LDR, Ramirez JB, Baez EO, Walteros DM, Martinez MLO, Mercado-Reyes M. 2020. Substitutions in Spike and Nucleocapsid proteins of SARS-CoV-2 circulating in Colombia. medRxiv. DOI: 10.1101/2020.06.02.20120782.

Gerritz SW, Cianci C, Kim S, Pearce BC, Deminie C, Discotto L, McAuliffe B, Minassian BF, Shi S, Zhu S, Zhai W, Pendri A, Li G, Poss MA, Edavettal S, McDonnell PA, Lewis HA, Maskos K, Mortl M, Kiefersauer R, Steinbacher S, Baldwin ET, Metzler W, Bryson J, Healy MD, Philip T, Zoeckler M, Schartman R, Sinz M, Leyva-Grado VH, Hoffmann HH, Langley DR, Meanwell NA, Krystal M. 2011. Inhibition of influenza virus replication via small molecules 
407

408

409

410

411

412

413

414

415

416

417

418

419

420

421

422

423

424

425

426

427

428

429

430

431

432

433

434

435

436

437

438

439

440

that induce the formation of higher-order nucleoprotein oligomers. Proceedings of the National Academy of Sciences of the United States of America. DOI: 10.1073/pnas.1107906108.

Gordon DE, Jang GM, Bouhaddou M, Xu J, Obernier K, White KM, O’Meara MJ, Rezelj V V., Guo JZ, Swaney DL, Tummino TA, Huettenhain R, Kaake RM, Richards AL, Tutuncuoglu B, Foussard H, Batra J, Haas K, Modak M, Kim M, Haas P, Polacco BJ, Braberg H, Fabius JM, Eckhardt M, Soucheray M, Bennett MJ, Cakir M, McGregor MJ, Li Q, Meyer B, Roesch F, Vallet T, Mac Kain A, Miorin L, Moreno E, Naing ZZC, Zhou Y, Peng S, Shi Y, Zhang Z, Shen W, Kirby IT, Melnyk JE, Chorba JS, Lou K, Dai SA, Barrio-Hernandez I, Memon D, Hernandez-Armenta C, Lyu J, Mathy CJP, Perica T, Pilla KB, Ganesan SJ, Saltzberg DJ, Rakesh R, Liu X, Rosenthal SB, Calviello L, Venkataramanan S, Liboy-Lugo J, Lin Y, Huang XP, Liu YF, Wankowicz SA, Bohn M, Safari M, Ugur FS, Koh C, Savar NS, Tran QD, Shengjuler D, Fletcher SJ, O'Neal MC, Cai Y, Chang JCJ, Broadhurst DJ, Klippsten S, Sharp PP, Wenzell NA, Kuzuoglu D, Wang HY, Trenker R, Young JM, Cavero DA, Hiatt J, Roth TL, Rathore U, Subramanian A, Noack J, Hubert M, Stroud RM, Frankel AD, Rosenberg OS, Verba KA, Agard DA, Ott M, Emerman M, Jura N, von Zastrow M, Verdin E, Ashworth A, Schwartz O, d'Enfert C, Mukherjee S, Jacobson M, Malik HS, Fujimori DG, Ideker T, Craik CS, Floor SN, Fraser JS, Gross JD, Sali A, Roth BL, Ruggero D, Taunton J, Kortemme T, Beltrao P, Vignuzzi M, García-Sastre A, Shokat KM, Shoichet BK, Krogan NJ. 2020. A SARS-CoV-2 protein interaction map reveals targets for drug repurposing. Nature. DOI: 10.1038/s41586-020-2286-9.

Hou S, Kumar A, Xu Z, Airo AM, Stryapunina I, Wong CP, Branton W, Tchesnokov E, Götte M, Power C, Hobman TC. 2017. Zika Virus Hijacks Stress Granule Proteins and Modulates the Host Stress Response. Journal of Virology. DOI: 10.1128/jvi.00474-17.

Kang S, Yang M, Hong Z, Zhang L, Huang Z, Chen X, He S, Zhou Z, Zhou Z, Chen Q, Yan Y, Zhang C, Shan H, Chen S. 2020. Crystal structure of SARS-CoV-2 nucleocapsid protein RNA binding domain reveals potential unique drug targeting sites. Acta Pharmaceutica Sinica B. DOI: 10.1016/j.apsb.2020.04.009.

Khan MI, Khan ZA, Baig MH, Ahmad I, Farouk A-E, Song YG, Dong J-J. 2020. Comparative genome analysis of novel coronavirus (SARS-CoV-2) from different geographical locations and the effect of mutations on major target proteins: An in silico insight. PloS one 15:e0238344. DOI: 10.1371/journal.pone.0238344.

Korber B, Fischer W, Gnanakaran SG, Yoon H, Theiler J, Abfalterer W, Foley B, Giorgi EE, Bhattacharya T, Parker MD, Partridge DG, Evans CM, Silva T de, LaBranche CC, 
441

442

443

444

445

446

447

448

449

450

451

452

453

454

455

456

457

458

459

460

461

462

463

464

465

466

467

468

469

470

471

472

473

474

Montefiori DC, Group SC-19 G. 2020. Spike mutation pipeline reveals the emergence of a more transmissible form of SARS-CoV-2. bioRxiv. DOI: 10.1101/2020.04.29.069054.

Lin Y, Shen X, Yang RF, Li YX, Ji YY, He YY, Shi MD, Lu W, Shi TL, Wang J, Wang HX, Jiang HL, Shen JH, Xie YH, Wang Y, Pei G, Shen BF, Wu JR, Sun B. 2003. Identification of an epitope of SARS-coronavirus nucleocapsid protein. Cell research. DOI: 10.1038/sj.cr.7290158.

Liu K, Chen Y, Lin R, Han K. 2020. Clinical features of COVID-19 in elderly patients: A comparison with young and middle-aged patients. Journal of Infection. DOI: 10.1016/j.jinf.2020.03.005.

Liu SJ, Leng CH, Lien SP, Chi HY, Huang CY, Lin CL, Lian WC, Chen CJ, Hsieh SL, Chong P. 2006. Immunological characterizations of the nucleocapsid protein based SARS vaccine candidates. Vaccine. DOI: 10.1016/j.vaccine.2006.01.058.

Lo YS, Lin SY, Wang SM, Wang CT, Chiu YL, Huang TH, Hou MH. 2013. Oligomerization of the carboxyl terminal domain of the human coronavirus 229E nucleocapsid protein. FEBS Letters. DOI: 10.1016/j.febslet.2012.11.016.

Madeira F, Park YM, Lee J, Buso N, Gur T, Madhusoodanan N, Basutkar P, Tivey ARN, Potter SC, Finn RD, Lopez R. 2019. The EMBL-EBI search and sequence analysis tools APIs in 2019. Nucleic acids research. DOI: $10.1093 /$ nar/gkz268.

McBride R, van Zyl M, Fielding BC. 2014. The coronavirus nucleocapsid is a multifunctional protein. Viruses. DOI: 10.3390/v6082991.

Onat Kadioglu MSHJGTE. 2020. Identification of novel compounds against three targets of SARS CoV2 coronavirus by combined virtual screening and supervised machine learning . Bull World Health Organ. DOI: 10.2471/BLT.20.251561.

Pachetti M, Marini B, Benedetti F, Giudici F, Mauro E, Storici P, Masciovecchio C, Angeletti S, Ciccozzi M, Gallo RC, Zella D, Ippodrino R. 2020. Emerging SARS-CoV-2 mutation hot spots include a novel RNA-dependent-RNA polymerase variant. Journal of Translational Medicine. DOI: 10.1186/s12967-020-02344-6.

Pettersen EF, Goddard TD, Huang CC, Couch GS, Greenblatt DM, Meng EC, Ferrin TE. 2004. UCSF Chimera - A visualization system for exploratory research and analysis. Journal of Computational Chemistry. DOI: 10.1002/jcc.20084.

Rabi Ann Musah. 2005. The HIV-1 Nucleocapsid Zinc Finger Protein as a Target of Antiretroviral Therapy. Current Topics in Medicinal Chemistry. DOI: 10.2174/1568026043387331.

Rodrigues CHM, Pires DEV, Ascher DB. 2018. DynaMut: Predicting the impact of mutations on 
475

476

477

478

479

480

481

482

483

484

485

486

487

488

489

490

491

492

493

494

495

496

497

498

499

500

501

502

503

504

505

506

507

508

protein conformation, flexibility and stability. Nucleic Acids Research. DOI: 10.1093/nar/gky300.

Shang B, Wang XY, Yuan JW, Vabret A, Wu XD, Yang RF, Tian L, Ji YY, Deubel V, Sun B. 2005. Characterization and application of monoclonal antibodies against $N$ protein of SARS-coronavirus. Biochemical and Biophysical Research Communications. DOI: 10.1016/j.bbrc.2005.08.032.

Tung HYL, Limtung P. 2020. Mutations in the phosphorylation sites of SARS-CoV-2 encoded nucleocapsid protein and structure model of sequestration by protein 14-3-3. Biochemical and Biophysical Research Communications. DOI: 10.1016/j.bbrc.2020.08.024.

Wootton SK, Rowland RRR, Yoo D. 2002. Phosphorylation of the Porcine Reproductive and Respiratory Syndrome Virus Nucleocapsid Protein. Journal of Virology. DOI: 10.1128/jvi.76.20.10569-10576.2002.

Wu A, Peng Y, Huang B, Ding X, Wang X, Niu P, Meng J, Zhu Z, Zhang Z, Wang J, Sheng J, Quan L, Xia Z, Tan W, Cheng G, Jiang T. 2020a. Genome Composition and Divergence of the Novel Coronavirus (2019-nCoV) Originating in China. Cell Host and Microbe. DOI: 10.1016/j.chom.2020.02.001.

Wu F, Zhao S, Yu B, Chen YM, Wang W, Song ZG, Hu Y, Tao ZW, Tian JH, Pei YY, Yuan ML, Zhang YL, Dai FH, Liu Y, Wang QM, Zheng JJ, Xu L, Holmes EC, Zhang YZ. 2020b. A new coronavirus associated with human respiratory disease in China. Nature. DOI: 10.1038/s41586-020-2008-3.

Zeng W, Liu G, Ma H, Zhao D, Yang Y, Liu M, Mohammed A, Zhao C, Yang Y, Xie J, Ding C, Ma X, Weng J, Gao Y, He H, Jin T. 2020. Biochemical characterization of SARS-CoV-2 nucleocapsid protein. Biochemical and Biophysical Research Communications. DOI: 10.1016/j.bbrc.2020.04.136.

Zhou Z, Ren L, Zhang L, Zhong J, Xiao Y, Jia Z, Guo L, Yang J, Wang C, Jiang S, Yang D, Zhang G, Li H, Chen F, Xu Y, Chen M, Gao Z, Yang J, Dong J, Liu B, Zhang X, Wang W, He K, Jin Q, Li M, Wang J. 2020a. Heightened Innate Immune Responses in the Respiratory Tract of COVID-19 Patients. Cell Host and Microbe. DOI: 10.1016/j.chom.2020.04.017.

Zhou R, Zeng R, von Brunn A, Lei J. 2020b. Structural characterization of the C-terminal domain of SARS-CoV-2 nucleocapsid protein. Molecular Biomedicine 1:2. DOI: 10.1186/s43556-020-00001-4.

Zhu N, Zhang D, Wang W, Li X, Yang B, Song J, Zhao X, Huang B, Shi W, Lu R, Niu P, Zhan F, Ma X, Wang D, Xu W, Wu G, Gao GF, Tan W. 2020. A novel coronavirus from patients 
509 with pneumonia in China, 2019. New England Journal of Medicine. DOI:

$510 \quad 10.1056 /$ NEJMoa2001017.

511 Zúñiga S, Cruz JLG, Sola I, Mateos-Gómez PA, Palacio L, Enjuanes L. 2010. Coronavirus

$512 \quad$ Nucleocapsid Protein Facilitates Template Switching and Is Required for Efficient

513 Transcription. Journal of Virology. DOI: 10.1128/jvi.02011-09.

514 Zúñiga S, Sola I, Moreno JL, Sabella P, Plana-Durán J, Enjuanes L. 2007. Coronavirus

515 nucleocapsid protein is an RNA chaperone. Virology. DOI: 10.1016/j.virol.2006.07.046. 


\section{Table $\mathbf{1}$ (on next page)}

\section{IDR1 Mutations}

The table show the location and details of mutations identified in IDR1 of N-protein. 
1 Table 1:

\begin{tabular}{|c|c|c|c|}
\hline S. No. & $\begin{array}{c}\text { Wild type } \\
\text { residue }\end{array}$ & $\begin{array}{c}\text { Position of } \\
\text { mutation }\end{array}$ & $\begin{array}{c}\text { Mutated } \\
\text { residue }\end{array}$ \\
\hline 1 & Asp & 3 & Tyr \\
\hline 2 & Asn & 4 & Asp \\
\hline 3 & Pro & 6 & Thr \\
\hline 4 & Gln & 9 & His \\
\hline 5 & Pro & 13 & Leu \\
\hline 6 & Arg & 14 & His \\
\hline 7 & Gly & 18 & Cys \\
\hline 8 & Gly & 19 & Arg \\
\hline 9 & Pro & 20 & Leu \\
\hline 10 & Asp & 22 & Tyr \\
\hline 11 & Ser & 23 & Thr \\
\hline 12 & Gly & 30 & Ala \\
\hline 13 & Glu & 31 & Asp \\
\hline 14 & Arg & 32 & Leu \\
\hline 15 & Gly & 34 & Leu \\
\hline 16 & Ala & 35 & Thr \\
\hline 17 & Arg & 36 & Leu \\
\hline 18 & Arg & 40 & Cys \\
\hline 19 & Arg & 40 & Leu \\
\hline
\end{tabular}

2 
Table 2 (on next page)

IDR2 mutations

The table show the location and details of mutations identified in IDR2. 
1

Table 2:

\begin{tabular}{|c|c|c|c|}
\hline S. No. & $\begin{array}{l}\text { Wild type } \\
\text { residue }\end{array}$ & $\begin{array}{c}\text { Position of } \\
\text { mutation }\end{array}$ & $\begin{array}{c}\text { Mutated } \\
\text { residue }\end{array}$ \\
\hline 1 & Ser & 183 & Tyr \\
\hline 2 & $\operatorname{Arg}$ & 185 & Cys \\
\hline 3 & Arg & 185 & Leu \\
\hline 4 & Ser & 187 & Leu \\
\hline 5 & Ser & 188 & Leu \\
\hline 6 & Ser & 190 & Ile \\
\hline 7 & Arg & 191 & Leu \\
\hline 8 & Asn & 192 & Ser \\
\hline 9 & Ser & 193 & Ile \\
\hline 10 & Ser & 194 & Leu \\
\hline 11 & $\operatorname{Arg}$ & 195 & Ile \\
\hline 12 & Ser & 197 & Leu \\
\hline 13 & Pro & 199 & Ser \\
\hline 14 & Ser & 202 & Asn \\
\hline 15 & $\operatorname{Arg}$ & 203 & Lys \\
\hline 16 & Arg & 203 & Met \\
\hline 17 & Gly & 204 & Arg \\
\hline 18 & Thr & 205 & Ile \\
\hline 19 & Ala & 208 & Gly \\
\hline 20 & Arg & 209 & Lys \\
\hline 21 & $\operatorname{Arg}$ & 209 & Thr \\
\hline 22 & Ala & 211 & Ser \\
\hline 23 & Gly & 212 & Cys \\
\hline 24 & Asn & 213 & Tyr \\
\hline 25 & Gly & 215 & Ser \\
\hline 26 & Ala & 218 & Val \\
\hline 27 & Ala & 220 & Thr \\
\hline 28 & Gln & 229 & His \\
\hline 29 & Ser & 232 & Arg \\
\hline 30 & Ser & 232 & Thr \\
\hline 31 & Met & 234 & Ile \\
\hline 32 & Ser & 235 & Pro \\
\hline 33 & Ser & 235 & Phe \\
\hline 34 & Gly & 236 & Val \\
\hline 35 & Gly & 238 & Cys \\
\hline 36 & Gly & 243 & Cys \\
\hline 37 & Thr & 247 & Ala \\
\hline 38 & Lys & 249 & Arg \\
\hline 39 & Ser & 250 & Phe \\
\hline
\end{tabular}




\begin{tabular}{|l|l|l|l|}
\hline 40 & Ala & 252 & Ser \\
\hline 41 & Ser & 255 & Ala \\
\hline
\end{tabular}

2 


\section{Table 3 (on next page)}

\section{IDR3 mutations}

The table show the location and details of mutations identified in IDR3. 
1 Table 3:

\begin{tabular}{|c|c|c|c|}
\hline S. No. & $\begin{array}{c}\text { Wild type } \\
\text { residue }\end{array}$ & $\begin{array}{c}\text { Position of } \\
\text { mutation }\end{array}$ & $\begin{array}{c}\text { Mutated } \\
\text { residue }\end{array}$ \\
\hline 1 & Pro & 365 & Ser \\
\hline 2 & Pro & 365 & Leu \\
\hline 3 & Asp & 377 & Tyr \\
\hline 4 & Asp & 377 & Gly \\
\hline 5 & Thr & 379 & Ile \\
\hline 6 & Gln & 380 & His \\
\hline 7 & Ala & 381 & Val \\
\hline 8 & Pro & 383 & Ser \\
\hline 9 & Pro & 383 & Leu \\
\hline 10 & Gln & 386 & Lys \\
\hline 11 & Gln & 386 & His \\
\hline 12 & Thr & 391 & Ile \\
\hline 13 & Thr & 393 & Ile \\
\hline 14 & Ala & 397 & Ser \\
\hline 15 & Ala & 398 & Val \\
\hline 16 & Asp & 399 & Glu \\
\hline 17 & Ser & 413 & Ile \\
\hline 18 & Ser & 416 & Leu \\
\hline
\end{tabular}

2

3

4 
Table 4 (on next page)

RBD mutations

The table show the location and details of mutations identified in RBD of N-protein 
1 Table 4:

\begin{tabular}{|c|c|c|c|}
\hline S. No. & $\begin{array}{c}\text { Wild type } \\
\text { residue }\end{array}$ & $\begin{array}{c}\text { Position of } \\
\text { mutation }\end{array}$ & $\begin{array}{c}\text { Mutated } \\
\text { residue }\end{array}$ \\
\hline 1 & Pro & 46 & Ser \\
\hline 2 & Glu & 62 & Val \\
\hline 3 & Pro & 67 & Ser \\
\hline 4 & Asp & 81 & Tyr \\
\hline 5 & Ala & 90 & Ser \\
\hline 6 & Ala & 119 & Ser \\
\hline 7 & Pro & 122 & Leu \\
\hline 8 & Ala & 125 & Thr \\
\hline 9 & Asp & 128 & Tyr \\
\hline 10 & Asn & 140 & Thr \\
\hline 11 & Pro & 142 & Ser \\
\hline 12 & Asp & 144 & Tyr \\
\hline 13 & Asp & 144 & His \\
\hline 14 & Ile & 146 & Phe \\
\hline 15 & Pro & 151 & Leu \\
\hline 16 & Ala & 152 & Ser \\
\hline 17 & Asn & 154 & Tyr \\
\hline 18 & Ala & 156 & Ser \\
\hline 19 & Gln & 163 & Arg \\
\hline 20 & Thr & 166 & Ile \\
\hline 21 & Lys & 169 & Arg \\
\hline 22 & Ser & 180 & Ile \\
\hline & & & \\
\hline
\end{tabular}

2 


\section{Table 5 (on next page)}

Dimerization domain mutations

The table show the location and details of mutations identified in dimerization domain of $\mathrm{N}$ protein. 
1 Table 5:

\begin{tabular}{|c|c|c|c|}
\hline S. No. & $\begin{array}{c}\text { Wild type } \\
\text { residue }\end{array}$ & $\begin{array}{c}\text { Position of } \\
\text { mutation }\end{array}$ & $\begin{array}{c}\text { Mutated } \\
\text { residue }\end{array}$ \\
\hline 1 & Val & 270 & Leu \\
\hline 2 & Thr & 271 & Ile \\
\hline 3 & Gly & 284 & Glu \\
\hline 4 & Gln & 289 & His \\
\hline 5 & Ile & 292 & Thr \\
\hline 6 & Gln & 294 & Leu \\
\hline 7 & Asp & 297 & Val \\
\hline 8 & Pro & 309 & Leu \\
\hline 9 & Met & 322 & Ile \\
\hline 10 & Ser & 327 & Leu \\
\hline 11 & Thr & 329 & Met \\
\hline 12 & Thr & 334 & Ile \\
\hline 13 & Asp & 340 & Gly \\
\hline 14 & Asp & 340 & Asn \\
\hline 15 & Asp & 348 & Tyr \\
\hline 16 & Thr & 362 & Ile \\
\hline 17 & Pro & 364 & Leu \\
\hline
\end{tabular}

2 
Table 6(on next page)

Frequency of $\mathrm{N}$-protein mutations

The frequency of top 10 mutations observed in this study 
1 Table 6:

\begin{tabular}{|c|c|c|}
\hline Mutation & $\begin{array}{l}\text { Number of samples that } \\
\text { harbour the mutation }\end{array}$ & \% frequency \\
\hline R203K & 207 & 4.97357 \\
\hline G204R & 196 & 4.709274 \\
\hline E62V & 39 & 0.937049 \\
\hline A208G & 24 & 0.576646 \\
\hline S183Y & 20 & 0.480538 \\
\hline S194L & 18 & 0.432484 \\
\hline T362I & 16 & 0.384431 \\
\hline T205I & 15 & 0.360404 \\
\hline P13L & 11 & 0.264296 \\
\hline R185C & 10 & 0.240269 \\
\hline & &
\end{tabular}

2 


\section{Table 7 (on next page)}

$\Delta \Delta \mathrm{G}$ and $\Delta \Delta$ Svib ENCoM calculations

The table show the $\Delta \Delta \mathrm{G}$ and $\Delta \Delta \mathrm{Svib}$ ENCoM of the mutants present in RBD and dimerization domain of N-protein. DynaMut programe was used to calculate both parameters. The top five positive and negative $\Delta \Delta \mathrm{G}$ values are highlighted in bold digits. The top three positive and negative $\Delta \Delta$ Svib ENCoM values are highlighted in bold digits. 
Table 7:

\begin{tabular}{|c|c|c|c|c|}
\hline S. No. & Mutant & PDB ID & $\begin{array}{c}\Delta \Delta G \\
(\mathrm{kcal} / \mathrm{mol})\end{array}$ & $\begin{array}{l}\Delta \Delta \text { SvibENCoM } \\
\text { (kcal.mol-1.K-1) }\end{array}$ \\
\hline 1 & E62V & 6VYO & 0.105 & 0.091 \\
\hline 2 & P67S & $6 \mathrm{VYO}$ & -0.486 & 0.16 \\
\hline 3 & D81Y & 6VYO & 0.454 & -0.425 \\
\hline 4 & A90S & 6VYO & 0.274 & 0.043 \\
\hline 5 & A119S & 6VYO & 0.073 & -0.069 \\
\hline 6 & $\mathrm{P} 122 \mathrm{~L}$ & $6 \mathrm{VYO}$ & -0.166 & -0.049 \\
\hline 7 & $\mathrm{~A} 125 \mathrm{~T}$ & 6VYO & -0.565 & -0.022 \\
\hline 8 & D128Y & 6VYO & 0.846 & -0.236 \\
\hline 9 & N140T & 6VYO & 0.318 & -0.177 \\
\hline 10 & P142S & 6VYO & 0.26 & -0.17 \\
\hline 11 & D144Y & 6VYO & 0.291 & -0.293 \\
\hline 12 & D144H & 6VYO & -0.036 & 0.06 \\
\hline 13 & I146F & 6VYO & 0.708 & -0.837 \\
\hline 14 & $\mathrm{P} 151 \mathrm{~L}$ & 6VYO & 0.771 & -0.14 \\
\hline 15 & A152S & 6VYO & 0.298 & -0.051 \\
\hline 16 & N154Y & 6VYO & -0.096 & -0.063 \\
\hline 17 & A156S & 6VYO & 0.428 & -0.256 \\
\hline 18 & Q163R & 6VYO & -0.092 & -0.017 \\
\hline 19 & T166I & 6VYO & 0.194 & -0.055 \\
\hline 20 & K169R & 6VYO & 0.231 & 0.077 \\
\hline 21 & V270L & 6WJI & 0.679 & -0.194 \\
\hline 22 & T271I & 6WJI & 1.184 & -0.472 \\
\hline 23 & G284E & $6 \mathrm{WJI}$ & 0.553 & -0.844 \\
\hline 24 & $\mathrm{Q} 289 \mathrm{H}$ & 6WJI & 0.18 & 0.181 \\
\hline 25 & I292T & 6WJI & -1.952 & 0.186 \\
\hline 26 & Q294L & 6WJI & 0.447 & -0.078 \\
\hline 27 & D297V & $6 \mathrm{WJI}$ & -0.113 & -0.072 \\
\hline 28 & P309L & 6WJI & 0.887 & -0.524 \\
\hline 29 & M322I & 6WJI & -0.348 & 0.045 \\
\hline 30 & S327L & 6WJI & 0.894 & -0.259 \\
\hline 31 & T329M & 6WJI & 0.569 & -0.189 \\
\hline 32 & T334I & 6WJI & 0.236 & -0.115 \\
\hline 33 & D340G & 6WJI & 0.398 & -0.114 \\
\hline 34 & D340N & 6WJI & 0.194 & -0.088 \\
\hline 35 & D348Y & $6 \mathrm{WJI}$ & 0.136 & -0.121 \\
\hline 36 & T3621 & 6WJI & 0.396 & 0.047 \\
\hline 37 & P364L & 6WJI & -0.061 & 0.256 \\
\hline
\end{tabular}

2 


\section{Figure 1}

The schematic structure of Nucleocapsid Phosphoprotein (N protein) of SARS-CoV-2.

The N-protein is comprised of 419 residues. The RNA-binding domain, dimerization domain, intrinsically disordered regions including IRD1, IRD2, and IRD3 are labelled. B-C) Cartoon representation of crystal structure of the RNA-binding domain (RCSB protein ID-6VYO) and dimerization domain (RCSB protein ID-6WJI) of N-protein. Panel B demonstrates the RBD while panel $\mathrm{C}$ represents dimerization domain of $\mathrm{N}$-protein. The identified mutated amino acids (single letter code) along with its respective position in polypeptide sequence are shown. The structural representations were made using UCSF chimera software tool.

A

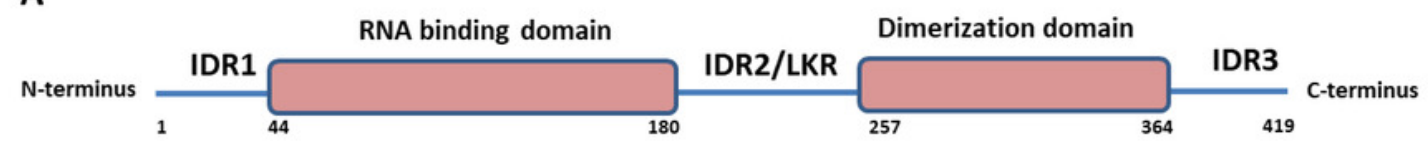

Nucleocapsid Phosphoprotein

B

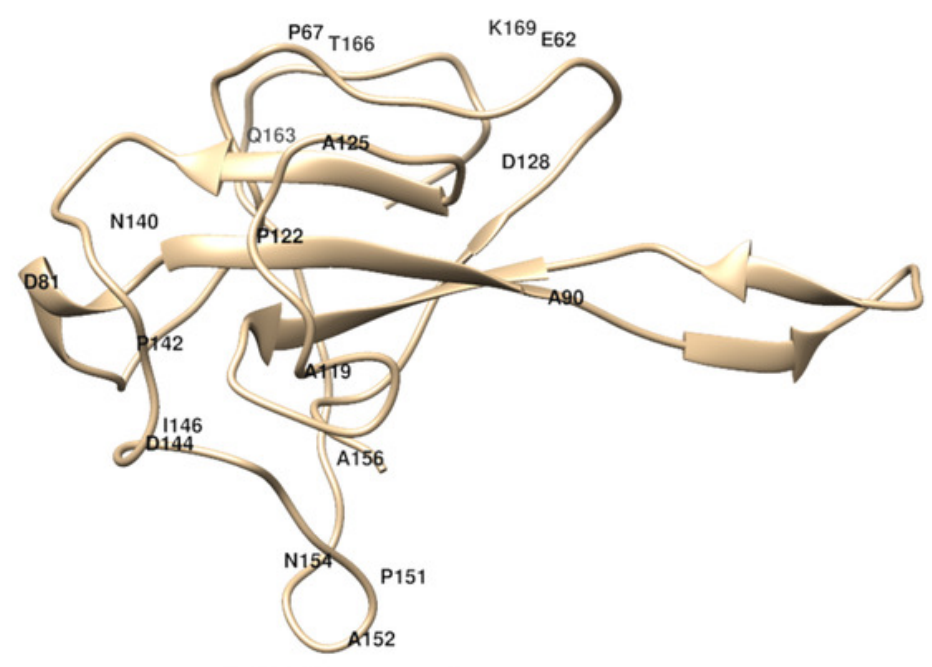

RNA-binding Domain c

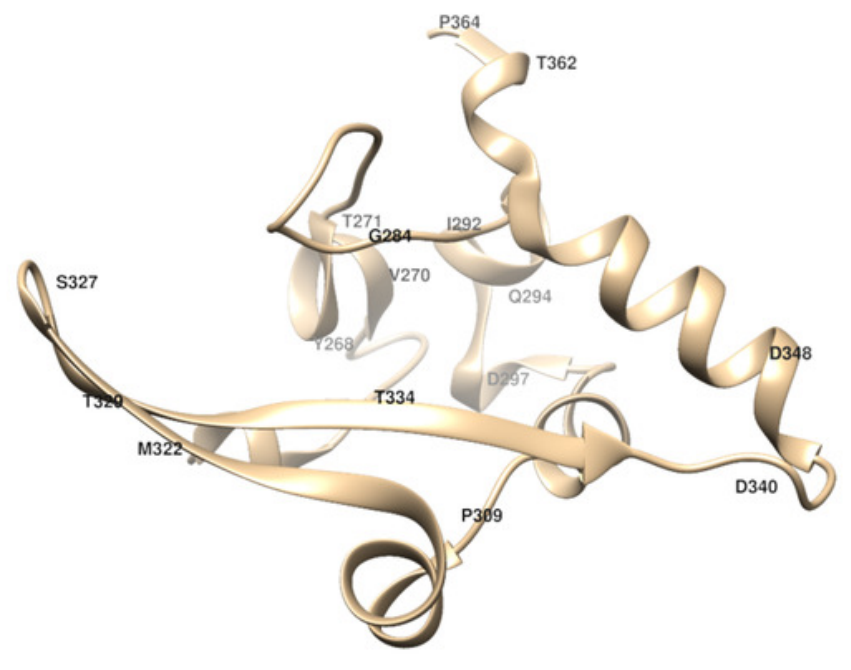

Dimerization Domain 
Figure 2

The weblogo diagram showing the conservation status of polypeptide sequence of $\mathrm{N}$ protein

The sequence weblogo was generated by multiple sequence alignment of $4164 \mathrm{~N}$-protein sequences. The overall height of the stack indicates the sequence conservation at that position. 

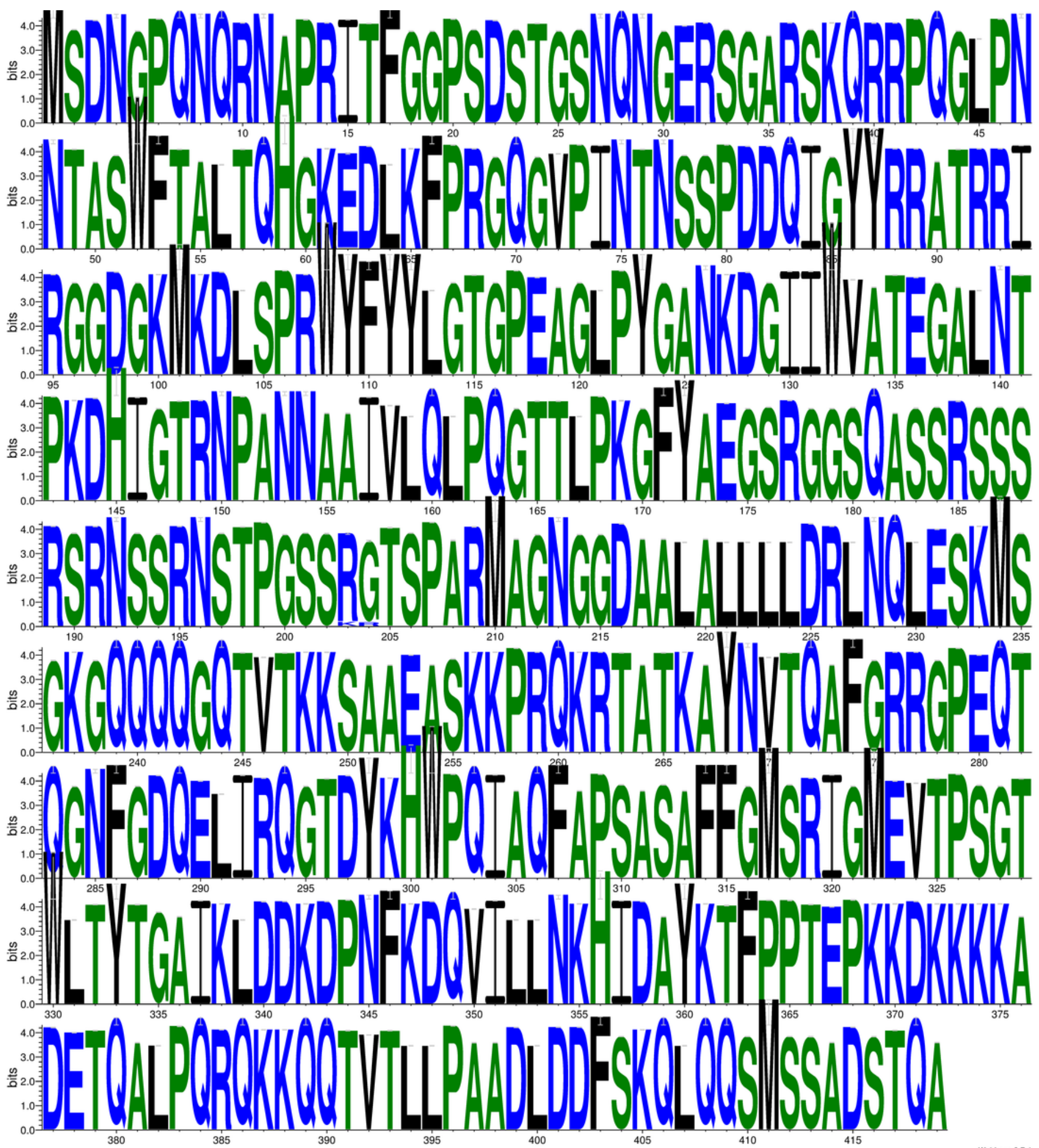
Figure 3

Visual representation of $\Delta$ Vibrational Entropy Energy between Wild-Type and Mutant $\mathrm{N}$ protein.

The amino acids residues are colored according to the vibrational entropy change as a consequence of mutation of N-protein.BLUE, represents a rigidification of the structure and RED, a gain in flexibility. $(A-C)$ represents the top three mutants that show rigidification in structure upon mutation. (D-F) represents the top three mutants that show gain in flexibility upon mutation. Each panel also shows the mutation and the location of the residues.
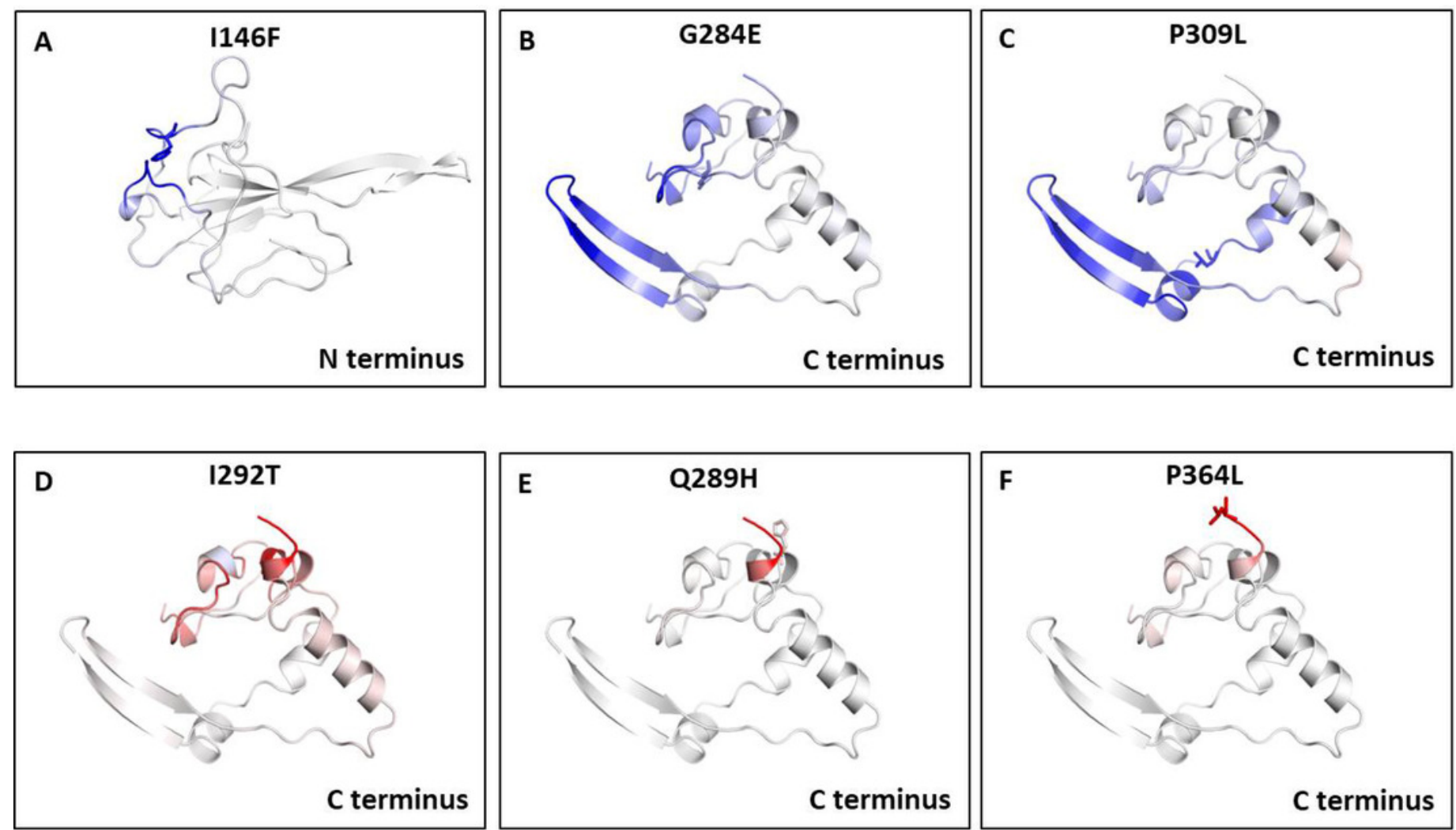


\section{Figure 4}

Analysis of interatomic interactions.

Visual representation of interatomic interactions contributed by T271I and I292T of N-protein. Both of these mutants showed maximum positive and negative $\Delta \Delta G$ among mutants present in RBD and dimerization domain of $\mathrm{N}$-protein. (A-B) represents threonine to isoleucine substitution at $271^{\text {st }}$ position; (C-D) represents isoleucine to threonine substitution at $292^{\text {nd }}$ position. Wild-type and mutant residues are represented in light-greencolor. The interactions made by wild type and mutant residues are highlighted in each panel. The polar interactions are depicted in red dotted line, hydrophobic interaction in green and weak hydrogen bonds in orange. 

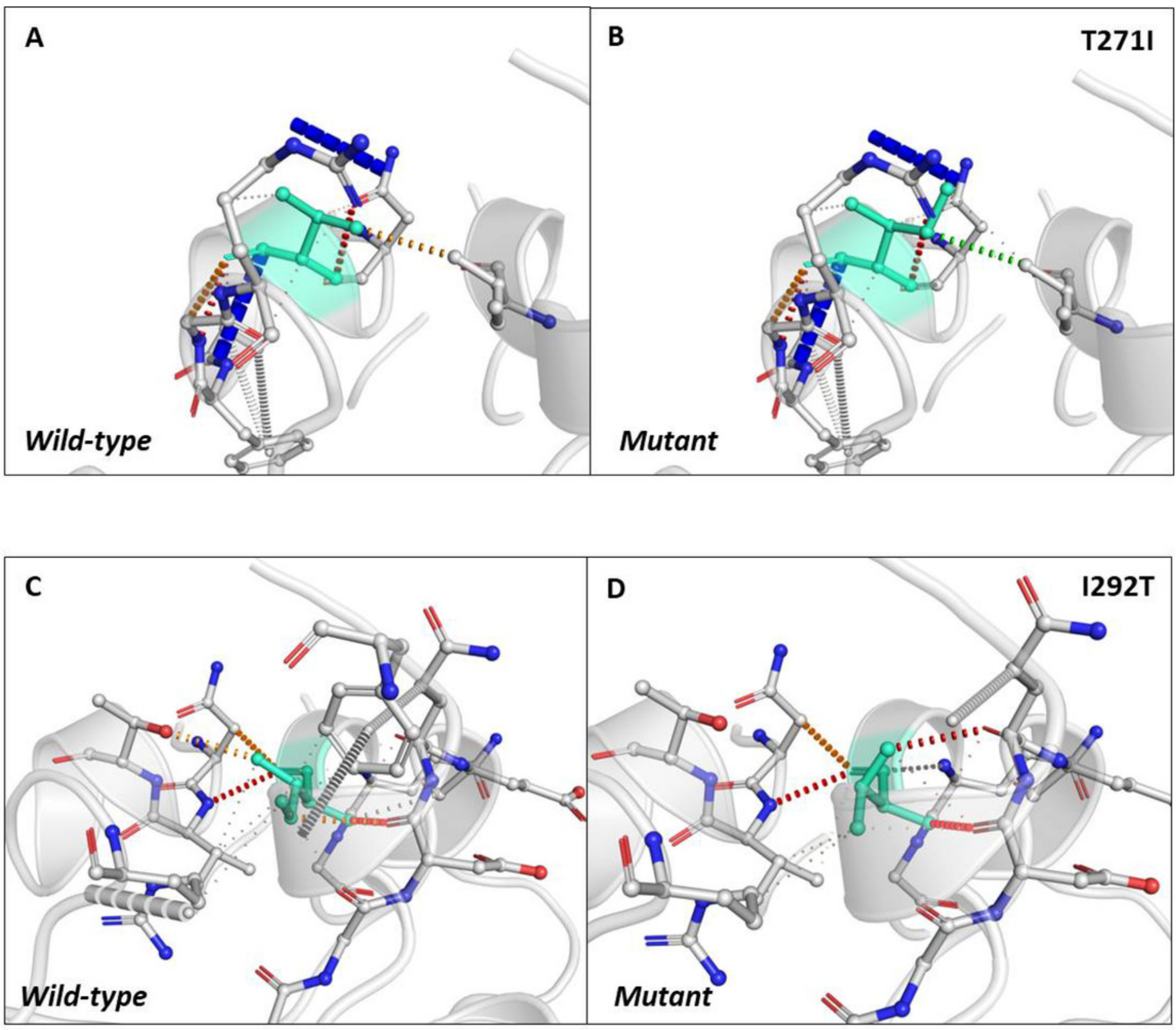